\title{
Gerakan Militan Islam Mesir dan Relevansinya dengan Politik Islam Indonesia:
}

\author{
Studi Gerakan Ikhwan al-Muslimun
}

\author{
Khoiruddin Nasution
}

\begin{abstract}
IKhwanul Muslimin was a political movement which had brought a huge impact toward political changes in Egypt. Under Hassan Al-Banna's leadership, Ikhwanul Muslimin had brought a new atmosphere of competitions, especially in power struggle competition in Egypt. The efforts of Egyptian government to restrain and to conquer the movement had faced massive challenge and constant fight back as well. This article will bring its readers to understanding of Islamic political movements and it will also encourage them to be able to explore Islamic political movements and their dynamism.
\end{abstract}

\section{Pendahuluan}

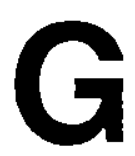

erakan Ikhwan al-muslimun yang didirikan Hasan al-Banna adalah salah satu gerakan militan Islam 'Mesir,' yang oleh sebagian penulis kadang-kadang disebut gerakan fundamentalis, sama dengan gelar yang diberikan kepada gerakan al-Maududi di Pakistan, Khumaidi di Iran, dan mungkin Khadafi di Libya. ${ }^{2}$ Sementara di Indonesia belum lama berdiri juga gerakan Darul Arqam, yang oleh Pemerintah Indonesia, lewat Majelis Ulama Indonesia (MUI) dilarang disebarluaskan, dengan alasan gerakan ini memiliki ajaran yang menyesatkan.

Tulisan ini mencoba memaparkan keberadaan gerakan Ikhwan al Muslimun ${ }^{3}$ pada masa rejim Anwar Sadat, yang kemudian akan dihubungkan dengan keberadaan gerakan militan Islam Indonesia, se-
'Abd al Monein Said Aly dan Manfred W. Wenner, "Modern Islamic Reform Movements: The Muslim Brotherhood on Contemporary Egypt," Middle East Journal 36: 3 (Summer 1982), hlm. 338-339.

${ }^{2}$ Nama fundamentalisme, atau kadang disebut terorisme adalah nama-nama yang dijulukkan barat kepada gerakan-gerakan konservatif Muslim. Maka meskipun sebutan fundamentalisme pada awalnya sebagai istilah untuk menyebutkan gerakan yang berkeringinan untuk kembali kepada ajaran agama (Kristen), tetapi istilah ini terkesan sebagai istilah yang negatif. Untuk menghindari kesan negatif tersebut, dalam tulisan ini penutis menggunakan istilah Gerakan Militan Islam atau Gerakan Politik Islam.

${ }^{3}$ Gerakan Ikhwan al-Muslimun diterjemahkan dalam bahasa Inggris dengan 'The Muslim Brotherhood'. Adapun Istilah yang digunakan dalam tulisan ini adalah 'lkhwan alMuslimun', seperti tertulis dalam judul tulisan. 
bagai gerakan politik Islam Indonesia. Untuk memudahkan pembahasan, tulisan ini dimulai dengan bahasan tentang eksistensi Gerakan Ikhwan al-Muslimun di masa Sadat, diteruskan dengan paparan kontekstualisasi gerakan Ikhwan al-Muslimun dengan Politik Islam Indonesia Kontemporer dan terakhir kesimpulan.

\section{Eksistensi Gerakan Ikhwan al-Muslimun pada Masa Sadat}

Untuk mengetahui perubahan yang terjadi dalam tubuh Ikhwan al-Muslimun di masa pasca Nasser, ada hal yang penting untuk diketahui. Pertama, Saudi Arabia di mata gerakan Ikhwan al-Muslimun merupakan negara yang mempunyai sistem politik yang betul-betul Islam, sebab Saudi Arabia menjadikan Shari'ah Islam satu-satunya sumber perundang-undangan. Karena itu, mereka mendorong Mesir untuk mengikuti jejak Saudi Arabia. Salah satu hasil dari penerapan hukum Islam di Arab Saudi menurut kelompok Ikhwan al-Muslimun adalah sangat rendahnya angka kriminal di Saudi Arabia. Mereka ingin mengislamkan kembali Mesir, yang selama ini, menurut mereka, sudah di bawah pengaruh paham komunis. Kedua, dengan kemampuan Saudi Arabia bekerja sama dengan Ikhwan al-Muslimun, akan mampu mempengaruhi pemerintah Mesir untuk mengubah kebijaksanaan luar negerinya yakni bekerja sama dengan Saudi Arabia sendiri. ${ }^{5}$

Pada awal memegang kekuasaan, Oktober 1970, setelah meninggalnya Nasser bulan September tahun yang sama, Sadat dianggap pemimpin yang lemah oleh kelompok Nasser. Namun perlu dicatat, dengan pengangkatan Sadat, gerakan Ikhwan alMuslimun sepertinya mendapat angin segar, sebab di samping mempunyai hubungan baik dengan gerakan ini, khususnya dengan alBanna, Sadat juga terkenal sebagai orang yang sangat cinta agama. Bahkan Sadat di masa pemerintahan Nasser sering dijadikan simbol oleh Nasser untuk menunjukkan kepada masyarakat bahwa pemerintahan yang dipimpinnya adalah pemerintahan yang Islami. Misalnya dipilinnya Sadat sebagai sekretaris Kongres Islam, yang didirikan tahun 1965, Sadat agak menjauh dari gerakan Ikhwan al-Musimun sejak adanya usaha membunuh Nasser. Sacht pertama bertemu al-Banna tahun 1940-an dan menghadiri kelas yang diberikan alBanna di kantor pusatnya di Kairo. ${ }^{6}$

Begitu Sadat nàik panggung (menjadi presiden menggantikan Nasser), slogan yang dipakai pun tidak tanggung-tanggung, yaitu keniscayaan iman dan sain. Sebagai perwujudan dari slogan ini, Sadat meñginstruksikan agar sholat lima waktu disiarkan lewat radio dan televisi. Kemudian menjanjikan akan menjadikan Shariah Islam sebagai landasan perundang-undangan, anggota Ikhwan al Muslimun yang masih berada di tahanan dikeluarkan oleh Sadat Mei 1.971, termasuk Hasan al-Hudaybi. Sadat menggunakan kekuasaan jema'ah lkhwan at-Muslimun untuk melawan kekuatan Marxisme.?

'Tulisan ini terkonsentrasi pada masa Sadat, sebab sebelumnya telah ditulis keberadaan Ikhwan al-Muslimun pada masa sebelum Sadat. Lihat Khoiruddin Nasution, "Hasan al-Banna dan Ikhwan al-Muslimun (Suatu Tinjauan Gerakan Pemikiran Sejak Berdiri Sampai Masa Gamal Abdul Nasser)", Al-Mawarid, edisi VI, Desember 1997, hlm. 104-113. 346.

sSaid Aly, "Modern Islamic Reform", hlm.

${ }^{6}$ Barrry Ruben, Islamic Fundamentalism in Egyption Politios (New York: St. Martin's Press, 1990), hlm. 16.

'Ruben, Islamic Fundamentalism, hlm. 16. 
Setelah memegang jabatan, Sadat melakukan empat kebijaksanaan baru; yaitu keterbukaan, demokratisasi, menerima bantuan dari Barat dan perbaikan hubungan dengan Israel. Keterbukaan yang dimaksud adalah mulai tahun 1977 pemerintah memberikan kesempatan kepada siapa saja untuk menamankam modalnya di Mesir, baik dari Mesir sendiri, dari Arab maupun dari luar.

Sedangkan penerapan dari kebijaksanaan demokratisasi adalah; (1) dengan memberikan kebebasan yang seluas-luasnya kepada gerakan militan Islam untuk mendirikan organisasi; (2) dengan membuka kembali kesempatan untuk munculnya multi partai, dan setiap partai diberi kesempatan secara bebas untuk mendirikan pers-nya masing-masing. Maka tidak mengherankan kalau anggota gerakan Ikhwan al-Muslimun yang sebelumnya lari ke luar Mesir, seperti mereka yang tinggal di Saudi Arabia dan kota-kota lainnya, kembali datang ke Mesir? Bahkan kebijaksanaan demokratisasi ini melahirkan militan Islam yang lebih radikal dari lkhwan al-Muslimun?

Tahun 1975 Sadat mengeluarkan amnestinya untuk kembali kepada sistem multipartai. Dengan adanya kebijaksanaan tersebut lkhwan al-Muslimun mendapat angin baru untuk kembali mengorganisir gerakannya ke kampus al-Azhar, sebagai pusat gerakan Islam. ${ }^{10}$ Kesuksesan Sadat dalam mengontrol pimpinan gerakan Ikhwan al-Muslimun dalam organisasi ternyata menimbulkan akibat lain, yaitu banyak militan yang meninggalkan kelompoknya untuk mendirikan kelompok baru, yang kebanyakan lebih radikal dari yang sudah ada, seperti Mukfirtiya (Pasukan Pelawan orang kafir), Jund Allah (Tentara Allah), Munnazamat al-Jihad (Organisasi Jihad), dan alTakfir wa alHijra (pengaduan dan perpindahan). Semua gerakan ini melawan rejim Sadat. Gerakan al-Takfir wa al-Hijra pertengahan
Januari 1977 melakukan pembakaran klubklub malam sepanjang.jalan di Kairo. Gerakan ini dipimpin oleh Ahmad Mustafa, seorang insinyur pertanian yang ditahan tahun 1965 sebagai aktivitas gerakan Ikhwan al-Muslimun. Setelah keluar dari tahanan Ahmad Musthafa kembali merekrut anggota untuk meneruskan gerakannya. Dia memang menyebut sebagai gerakan Jama'at al-Muslimin yang kemudian difokuskan ke al-Takfir wa al-Hirja. Temayang selalu diangkat adalah bahaya penyakit kemusyrikan (Shirk). Ahmad Musthafa berkeyakinan bahwa ilmu pengetahuan harus disebarluaskan dan akhirnya diikuti dengan jihad untuk mendirikan negara Islam. Gerakan ini kemudian menjadi gerakan yang sangat eksklusif: hidup di lingkungan mereka sendiri, nikah antara mereka, anak tidak dididik di sekolah negara dan menolak untuk ikut di militer. Pada tanggal 3 Juli 1977, Shaikh Muhammad Hussein al-Dha habi, bekas menteri agama dan orang penting di al-Azhar, diculik kelompok alTakfir wa al-Hirja yang akhirnya dibunuh. Alasan pembunuhannya adalah karena alDhahabi menulis ide yang menentang ide gerakan yang dipimpin Ahmad Mushafa ini. Akibat dari pembunuhan ini, 620 anggota gerakan al-Takfir wa al-Hirja ditahan, 465 diadili di pengadilan militer, 5 orang dihukum bunuh, salah satunya Ahmad Mustafa. Menurut catatan pemerintah, pengikut

${ }^{8}$ Dipid Hiro, The Rise of Islamic Fundamentalism (New York: An Imprint Rouledge, 1989), hlm. 70.

9Misalnya dengan lahirnya the Islamic Liberation Group. Bulan Juni 1974 gerakan yang sangat liberal ini berusaha membunuh Sadat, dengan tujuan untuk mendirikan negara Islam.

${ }^{10} \mathrm{Hiro}$, The Rise of Islamic Fundamentalism, hlm. 71. 
gerakan ini ada sekitar 3.000-5.000 orang, yang terdiri dari seluruh lapisan masyarakat dan lersobar dl selurulı penjuru nogura."

Hubungannya dengan kebijaksanaan Sadat dalam hal pemutaran kiprah ke Barat, ia mengkritik kebijaksanaan berkiprah dengan Sosialis Soviet yang dilakukan Nasser, dan begitu berkuasa, Sadat memutar kebijaksanaan untuk bekerja sama dengan Barat (Amerika Serikat). Hubungan kerja sama yang dijalin dengan Amerika bukan hanya di bidang ekonomi dan strategi, tetapi juga di bidang media massa, pertahanan, teknologi, perfilman dan saluran televisi.

Tentang kebijaksanaan perbaikan hubungan dengan Israel, Sadat sudah membuka diri untuk mengadakan hubungan mulai Februari 1971, tetapi Amerika Serikat dan Israel belum menanggapi secara serius. Pembicaraan itu dimulai lagi pada tahun 1973, yang terkenal dengan pertemuan Oktober 1973.12

Dengan adanya tanda-tanda semakin menguatnya perdamaian dengan Israel bulan Maret 1979, mahasiswa Islam mengadakan demonstrasi di jalan-jalan sepanjang kota Alexandria. Isi demonstrasi itu antara lain, "Tidak ada perdamaian dengan-Israel, tidak ada hak istimewa bagi orang kaya, akhiri dekadensi moral, dan tidak ada pemisahan antara Islam dan negara".

Keberanian para mahasiswa ini, barangkali, didukung oleh kemenangan Khomaini di Iran pada tahun yang sama. Hal ini membuat mahasiswa berani dan yakin akan adanya kemungkinan untuk mendapat kemenangan melawan pemerintah yang berkuasa. Usaha penolakan mahasiswa terhadap kebijaksanaan Sadat untuk mengadakan perdamaian dengan Israel, tidak cukup hanya dengan demonstrasi, tetapi juga ditambah dengan usaha menyebarluaskan lewat mass media. Dalam majalah al-Da'wa misalnya ditulis, "mustahil hidup berdamai dengan Israel". ${ }^{33}$ Sejak munculnya usaha penolakan terhadap kebijaksanaan

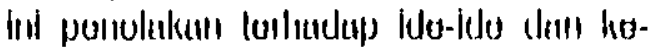
bijaksanaan-kebijaksanaan Sadat dalam banyak hal pun muncul semakin gencar, bahkan lkhwan al-Muslimun lewat al-Da'wa, menuduh Sadat menjual kemerdekaan Mesir kepada Amerika, sama dengan apa yang dilakukan Nasser kepada Soviet. ${ }^{14}$

Berbeda dengan gerakan militan Islam lainnya, Ikhwan al-Muslimun adalah kelompok yang paling vokal mengkritik kebijaksanaan Sadat. Mereka tidak bosan-bosan mengkritik ketidakbécusan kepemimpinan Sadat. Tanpa menyebut nama Sadat secara langsung, mereka menyebut sebagai pemerintahan yang tidak Islami, pemerintahan yang korup. Demikian juga dalam bidang ekonomi, gerakan ini juga selalu memberikan kritikan yang tajam. Mereka menyebut bahwa dengan kebijaksanaan ekonomi yang ada menciptakan ketidakadilan Sadat dituduh sebagai pemimpin yang gagal menanggulangi masalah pendidikan; perumahan, transportasi dan bahkan di bawah kepemimpinannya inflasi semakin tinggi. Mereka juga mengatakan dan sekaligus mengkritik bahwa slogan yang semula digembar-gemborkan berupa ilmu pengetahuan dan agama. (al-iim wa a/imän) masih tetap impian yang tidak pernah terwujud. ${ }^{15}$

'Hiro, The Rise of Islamic Fundamontalism, hlm. 72-73.

12Saad Eddin Ibralsim, "An Islamic Allornative in Egypl; The Muslim Brotherhood and Sadat," Arab Studies Quarterly 4: 1 \& 2 (1982), him. 77-80.

${ }^{13}$ Hiro, The Rise of Islamic Fundamentalism, hlm. 76.

"Hiro, The Aise of Islamic Fundamentalism, hlm. 78.

${ }^{15}$ lbrahim, "An Islamic Altematif in Egypr", hlm. 80-83 
Topik: Gerakan Militan Islam Mesir dan Relevansinya ..., Khoiruddin Nasution

Hubungannya dengan kebijaksanaan demokratisasi, Ikhwan al-Muslimun tidak menganggapnya sebagai hak istimewa, tetapi lebih banyak diyakini sebagai hak umat. Mereka menawarkan sistem musyawarah (shīra'), yaitu demokrasi yang didasarkan pada pemilihan umum yang bebas. Mereka berargumen, wakil-wakil rakyat yang dipilih melalui pemilihan yang bebas harus benar-benar dijadikan tempat konsultasi untuk menentukan kebijaksanaan pemerintah. ${ }^{16}$

Said Aly kembali membagi periodisasi Sadat kepada dua periode. Pertama, Periode 1970-1978 yang dianggap sebagai masa bermanis-manis antara Sadat dengan Ikhwan al-Muslimun. Kedua, tahun 19781981, sebagai masa konfrontasi. Alasan yang dicatat sebagai sebab terjadinya konfrontasi ada dua: (1) karena adanya usaha untuk berdamai dengan Israel; (2) pengaruh keberhasilan revolusi Iran.

Pada periode pertama Sadat memang menghadapi dua situasi politik yang cukup berat. Pertama, dia mempunyai keinginan untuk membawa Mesir kepada teori-teori barat secara umum, khususnya bekerjasama dengan Amerika Serikat. Sebab dia yakin hanya negara ini yang bisa memberikan bantuan memperbaiki ekonomi Mesir. Demikian juga dia melihat bahwa hanya negara ini yang bisa membantu memperbaiki hubungan dengan Israel. Karena itu, dia membuka kebijaksanaan baru berupa keterbukaan. Kedua, Sadat juga sangat tergantung pada Saudi Arabia dalam hal operasi pemerintahan. Sebaliknya, dia juga sadar bahwa dengan kebijaksanaan keterbukaan itu akan menimbulkan dampak yang sangat banyak, termasuk pengorbanan nilai-nilai, dan akan menciptakan kesenjangan kelas. Untuk menutupi kelemahan ini dia menggunakan lembaga agama. Salah satu usaha yang dilakukan lewat lembaga agama adalah dengan bekerja sama dengan lkhwan al-Muslimun. Bersamaan dengan itu, dia juga berharap agar Ikhwan al-Muslimun bisa bekerja sama dengannya untuk melawan kelompok kiri. ${ }^{7}$

Untuk menindaklanjuti kebijaksanaan ini, bulan Juli 1977, pada kongres organisasi Islam yang diadakan di bawah kepemimpinan rektor Al-Azhar, Shaikh Abdul Halim Mahmud, disampaikan deklarasi, semua perundang-undangan akan didasarkan pada Shari'ah, dan putusan yang bertentangan dengan Islam akan dianggap salah. Akhirnya, kongres sangat senang, sebab di samping apa yang disampaikan rektor Al-Azhar tersebut juga diikuti dengan catatan presiden, yang mengatakan bahwa akan diadakan pembersihan pada administrasi negara yang mempunyai unsur ateis. Segera setelah itu Sadat mengumumkan penggantian hukum Perancis dengan hukum Islam. Negara juga mengumumkan bahwa hukuman terhadap pelaku minuman keras dan zina akan diperlakukan dengan hukum Islam. Adapun operasionalnya sedang dipelajari. Demikian juga hukuman terhadap pencuri sedang dipelajari kemungkinan diperlakukannya. Orang Islam tentu saja sangat senang dengan kebijaksanaan tersebut, namun orang Kristen, yang jumlahnya 10 persen dari penduduk Mesir, merasa keberatan. Maka pada awal September 1977, dengan dipimpin oleh pimpinan gereja, melakukan unjuk rasa dan mengingatkan untuk pembatalan rencana

${ }^{16}$ Ibrahim, "An Islamic Allematif in Egypl," hIm. 83-85.

"Said Aly, "Modem Islamic Reform," hlm. 354.

${ }^{18} \mathrm{Hiro}$, The Rise of Islamic Fundamentalism, hlm. 74.

'19Joseph P. O'kane, "Islam in the New Egyption Constitution," The Middle East Journal 26: 2 (Spring 1972), hlm. 138. 
tersebut. Akhirnya Sadat pun membatalkannya. ${ }^{18}$ Namun perlu dicatat, pada awal proses penerapan Islam sebagai agama negara, non-Islam, yang diwaili oleh Koptic, menyetujui penerapannya. ${ }^{19}$

Keberhasilan revolusi Iran sangat mempengaruhi sikap Sadat terhadap gerakan Ikhwan al-Muslimun. Keberhasilan ini sepertinya memberikan kepercayaan kepada Sadat tentang adanya kemungkinan berhasilnya gerakan Ikhwan al-Muslimun menggulingkan kekuasaannya. Akibatnya, Sadat sangat hati-hati dengan gerakan militan Islam, termasuk Ikhwan al-Muslimun. Akibat selanjutnya, hubungan mesranya dengan Ikhwan al-Muslimun berubah menjadi konflik. Sikap kekhawatiran itu dapat dilihat dengan pengumuman bahwa pemerintah tidak mengizinkan pembentukan partai Islam. Padahal sebelumnya sudah diumumkan kebebasan mendirikan partai. Akibatnya, terjadilah demonstrasi dan unjuk rasa yang berkepanjangan, yang bukan saja mendemonstrasikan dan protes terhadap sikap mendua Sadat, tetapi juga termasuk protes terhadap dampak negatif dari kebijaksanaan keterbukaan, yaitu semakin banyaknya jumlah klub-klub malam, pelacuran, judi, penjualan alkóhol dan semacamnya. Sebab dengan kebijaksanaan Sadat ini juga membuka liberalisasi kaum Hawa. Tahun 1979 misalnya Sadat mengumumkan (1) bahwa 30 wakil di DPR harus wanita; (2) adanya pembatasan yang baru tentang cerai dan poligami. ${ }^{20} \mathrm{Kebijaksanaan}$ ini dianggap bertentangan dengan hukum Islam.

Dengan demikian, al-Banna ingin men. coba mengubah masyarakat Muslim Mesir yang tinggal dalam segala bidang kehidupan, seperti pendididikan, keadilan, kepedulian, ekonomi dan lain sebagainya, untuk menjadi lebih baik dan maju, yang didasarkan pada nilai Islam. Sebab berdasar bukti sejarah, dengan pendekatan modernisme, menurut al-Banna ternyata tidak mampu mengangkat derajat dan kondisi masyarakat Mesir menjadi lebih baik. Masih menurut kaca mata dia, apa yang terjadi di Mesir malah justru sebaliknya, korupsi merajalela, kesenjangan antara di miskin dengan si kaya semakin melebar, keadilan tidak pernah tercipta. Dengan begitu, ada dua kerugian yang muncul pada masyarakat Muslim Mesir. Pertama kehilangan nilai-nilai agama karena pengaruh budaya barat, yang pada gilirannya menciptakan prajurit-prajurit yang tidak bermoral. Kedua, dominasi orang luar terhadap Mesir menjadi semakin menguat. Akibatnya, ketergantungan terhadap orang lain semakin besar pula. Apa yang dikritik alBanna memang dapat dibuktikan dengan melihat bagaimana ketergantungan mesir terhadap. Uni Soviet di masa Nasser dan Amerika Serikat pada periode sesudahnya sampai sekarang.

\section{Kontekstualitas Gerakan Ikhwan al-Muslimun}

Dari gambaran tersebut di atas, terlihat ada dua alasan pokok yang mendorong alBanna mendirikan gerakan Ikhwan alMuslimun. Pertama, keinginan agar Mesir dapat lepas dari dominasi negara lain, sebab dominasi luar terhadap kehidupan masyarakat Mesir hampir terjadi di segala bidang kehidupan. Dominasi ini, minimal di mata al-Banna, tidak memberikan kehidupan yang lebih baik untuk kehidupan masyarakat Mesir. Memang diakui bahwa dominasi tersebut memberikan perubahan yang cukup banyak, namun sejalan dengan itu juga menimbulkan kesenjangan yang semakin menganga antara kelas atas

${ }^{20}$ Said Aly, "Modern Islamic Reform," hlm. 355-356. 
dengan kelas bawah, kehancuran moral dan ideologi. Al-Banna sendiri pernah mengatakan:

Setelah selesainya perang dan selama saya tinggal di Kairo kesenjangan di bidang moral dan ideologi terlihat semakin jelas. Kesenjangan ini terjadi dengan mengatasnamakan kemerdekaan berpikir. Demikian juga terlihat perubahan sikap, moràl dan perbuatan, yang juga mengatasnamakan kebebasan berpikir. Buku-buku dan majalahmajalah ditujukan untuk melemahkan dan merusak nilai agama masyarakat, anak-anak muda kehilangan pijakan, pendidikan yang diberikan pemerintah membingungkan masyarakat. Dominasi Barat merambah hampir di segala bidang kehidupan, seperti keuangan, kekayaan, kekuasaan. Propaganda penguasa semakin menguat. Saya merasa sedih melihat perlakuan barat terhadap agama. ${ }^{21}$

Apa yang dicatat al-Banna tersebut memang dapat dibuktikan dengan keberadaan perkembangan Mesir, khususnya semenjak rejim Muhammad Ali. Rejim Muhammad Ali Pasha (1805-1849) dicatat sebagai awal pemisahan antara lembaga agama dan negara di Mesir. Puncaknya terjadi pada tahun 1809-1813, ketika Muhammad Ali Pasha memecat para ulama yang menen tang idenya. Kemudian diteruskan dengan penolakannya terhadap nasihat para ulama yang berhubungan dengan unusan negara. ${ }^{22}$

Kaitannya dengan pusat-pusat pendidikan, menurut laporan satu penelitian, menjelang tahun 1875 , kebanyakan sekolah diubah menjadi masjid. Gaji para ulama diputus, kecuali ulama yang mengajar di al-Azhar. Bahkan masjid-masjid yang tidak mampu mendapatkan dana untuk kelangsungannya diubah menjadi tempat pertemuan atau gedung serba guna. ${ }^{23}$
Sejalan dengan itu, pabrik-pabrik didirikan hanya untuk memenuhi kebutuhan militer, seperti kebutuhan senjata, pakaian seragam dan amunisi. Pusat-pusat pendi dikan yang dibangun, baik sekolah umum, pendidikan kesehatan maupun keterampilan-keterampilan juga hanya untuk memenuhi kebutuhan militer. ${ }^{24}$

Usaha modernisasi di bidang lain, seperti ekonomi, institusi, dan lain-lain, mulai digalakkan di pertengahan kedua Abad ke19, yang dilakukan oleh Khedive Ismail (1863-1879). Pada periode ini pembangunan memang mulai menyentuh ke segala aspek kehidupan dan diperuntukkan bagi masyarakat secara luas. Sayangnya, Ismail dirasa terlalu mengutamakan institusi sekuler, dan kurang memberikan perhatian terhadap institusi agama. Sekolah-sekolah madrasah, seperti Madrasah Tsanawiyah (MTs), Madrasah. Aliyah (MA) dan semacamnya misalnya menjadi kelas dua setelah sekolahsekolah umum seperti SD, SMP, SMA dan perguruan tinggi umum. Padahal sekolahsekolah umum ini di samping didirikan negara, banyak juga yang dikelola nonMuslim yang minoritas. Semua pengembangan di bidang politik dan ekonomi didasarkan pada konsep Barat. ${ }^{25}$

Patut juga dicatat, sebagaimanaditulis Gabriel Baer, meskipun usaha modernisasi

2Hasan at-Bannâ, Mudhakkirât Hasan alBannã '(Kairo, tnp., 1949., 1949), hlm. 56-59.

${ }^{22}$ Daniel Crecelius, "The Course of Secularization in Modern Egypt," dalam John L. Esposito, ed. Islam and Development: Religion and Sociopolitical Change (New York: Syracus University Press, 1980), hlm. 52.

${ }^{23}$ Crecelius, "The Course of Secularization," 54-55.

${ }^{24}$ Crecelius, "The Course of Secularization," 56-60.

${ }^{25}$ Crecelius, "The Course of Secularization," 56-60. 
yang dilakukan Khedive Ismail pada awalnya menyentuh kepentingan orang banyak, lambāt laun di samping merusak institusiinstitusi agama, ternyata juga hanya me rubah nasib mereka-mereka yang berada di kelas atas. Sementara untuk kelas bawah hampir tidak memberikan nilai tambah.6

Maka pertentangan antara kelompok konservatif dan modernis yang terjadi di Mesir diduga sangat mempengaruhi pemikiran dan falsafat Al-Banna. Terbukti, dia sendiri berkomentar:

Tidak ada tuhan selain Allah yang Maha Mengetahui tentang berapa malam yang sudah kita habiskan dalam rangka berpetualangan mengelilingi negara kita, untuk melihat bermacamragam kehidupan dan dampak negatif dari penyakit kehidupan masyarakat. Sekarang kita berpikir tentang bagaimana cara menanggulangi penyakit tersebut. Kita berdiskusi dengan panjang lebar dalam rangka mengambil keputusan terbaik untuk usaha penanggulangan penyakit. Ketika berdiskusi, bagaimana kita kaget ketika membandingkan pandangan kita dengan pandangan orang lain yang sedang terperdaya dengan keenakan kue yang ada. ${ }^{27}$

Faktor kedua yang mempengaruhi pemikiran Al-Banna adalah latar belakang pendidikannya yang berasal dari keluarga Hanbali yang fundamentalis. Seperti diketahui, Madhab Hanbali adalah aliran yang senantiasa mencoba mengadakan pembersihan (purifikasi) terhadap ajaran agama Islam. Sebab, menurut mereka, ajaran yang diamalkan muslim bukan lagi Islam murni, tetapi sudah tercampuri dengan bid'ah, khurafat dan semacamnya. Dengan demikian, tidak menutup kemungkinan pengaruh pe mikiran Ibn Taymiyyah juga ikut mempengaruhi dan membentuk pemikiran Al-Banna. Di samping itu, ada juga kemungkinan karena pengaruh Pan-Islam Al-Afghânî. Pe ngaruh Al-Afghânî dapat dilihat misalnya lewat teori mereka yang kental dengan konsep Islamic Umma, yang terdiri dari tiga komitmen; komitmen politik terhadap negara sendiri, komitmen terhadap wilayah Arab dan komitmen terhadap Islam secara keseluruhan. ${ }^{28}$

Hal lain yang juga penting dicatat adalah bahwa perkembangan yang pesat dari gerakan ini bukan saja karena kebrilyanan dan kemampuan Al-Banna, tetapi tidak menutup kemungkinan bahwa sebenarnya orang sudah demikian bosan dengan keberadaan dominasi Barat. Dengan demikian, gerakan ini sebenarnya sudah lama dinantikan kehadirannya oleh masyarakat.

Salah seorang pemimpin Ikhwan alMuslimun yang cukup berpengaruh pernah mengatakan:

Mesir sudah berjanji sejak revolusi bulan Juli 1952 untuk memperbaiki keadaan Mesir, tetapi kenyataan tidak pernah muncul, yang ada malah keadaan ekonomi yang semakin jelek dan semakin terpuruk, kekuatan militer tambah lemah, dan kesejahteraan sosial tidak pemah terwujudkan karena tidak pernah menerapkan Shari'a. ${ }^{29}$

Jadi apa yang diharapkan gerakangerakan semacam Ikhwan al-Muslimun mulai dari awal berdirinya sampai sekarang, hanyalah ingin diberi kesempatan untuk menerapkan teorinya, sebagaimana para modernis diberikan kesempatan menerapkan teori mereka. Kemudian lihat hasilnya mana yang lebih baik. Mereka bosan dengan slogan-slogan modernis yang ternyata tidak memberikan hasil yang terbaik, tetapi malah sebaliknya. Sementara para gorakan militan tidak pernah diberikan kesempatan untuk menguji dan mencoba teori dan kepercayaannya. 


\section{Konteks Politik Muslim Indonesia}

Hubungannya dengan keberadaan kelompok-kelompok jamaah atau dengan sebutan Darul Arqam, atau label apa saja, yang ada dan berkembang di Indonesia dan Malaysia, menurut hemat penulis barangkali merupakan pengembangan dari gerakan-gerakan yang ada dan berkembang di Timur Tengah. Bagaimana pengaruh gerakan Ikhwan al-Muslimun dengan gerakan Darul Arqam dan semacamnya, sama kira-kira dengan pengaruh gerakan Wahabisme dan Muhammad 'Abduh dari Mesir dan gerakan pembaharuan pemikiran Islam di Indonesia. Hampir semua gerakan ini dibawa oleh para pelajar dan mahasiswa yang pernah belajar ke Timur Tengah. Khusus untuk gerakan seperti Darul Arqam, secara umum dibawa pelajar dan mahasiswa dari Timur Tengah, ditambah beberapa dari muslim Indonesia dari Barat.

Adapun faktor pendorong pengikut gerakan ini untuk membawa ajaran dan gerakan ini ke Indonesia, kemungkinan ada tiga faktor pokok. Pertama murni hanya keinginan untuk mengembangkan gerakan, karena barangkali ada tuntutan dari doktrin gerakannya. Kemungkinan kedua adalah karena adanya ketidakpuasan terhadap kebijaksanaan pemerintah yang sedang memegang kekuasaan. Ketiga, karena melihat kebejatan moral yang semakin melanda muslim Indonesia. Dengan demikian, mereka ingin membentuk masyarakat yang benar-benar berdasar pada ajaran Islam murni, seperti yang mereka percayai. Karena itu, tindakan pemerintah untuk melarang keberadaan gerakan ini, dalam hal ini dengan menggunakan tangan MUI, menurut penulis, lebih banyak didasarkan pada kekhawatiran politik dari pada pertimbangan kesesatan ajaran. Penulis memang belum mengadakan penelitian lapangan secara khusus, namun melihat amalan para pengikut kelompok ini, terdapat tanda-tanda bahwa apa yang mereka lakukan bukanlah praktek yang sesat dan melenceng dari nilai dan ajaran agama Islam, melainkan satu alternatif penafsiran, sama bobotnya dengan penalsiran-penafsiran lain. Adalah juga bukti bahwa masyarakat Darul Arqam adalah komunitas yang ingin membangun ekonomi dan perdagangan bersama yang tidak menciptakan kesenjangan antara si Kaya dan si Miskin. antara penguasa dan rakyat jelata, antara petani dan tuan tanah dan semacamnya. Mereka ingin menghanguskan praktek ekonomi dan perdagangan kapitalis yang menyengsarakan masyarakat lapis bawah.

Pertanyaan yang muncul adalah kenapa gerakan Ikhwan al-Muslimun di Mesir sampai sekarang belum berhasil menduduki tahta kekuasaan. Pertanyaan kedua, mungkinkah gerakan-gerakan semacam Darul Arqam dapat mengambil alih kekuasaan dari tangan penguasa di Indonesia, seperti keberhasilan revolusi Khomainy di Iran? Kalau pertanyaan kedua dipertajam akan berbunyi, mungkinkah adanya revolusi di Indonesia yang dimotori oleh kaum muslim?

Untuk menjawab pertanyaan pertama Ibrahim memberikan satu catatan, bahwa secara umum Ikhwan al-Muslimun dianggap sebagai gerakan yang positif oleh masyarakat Mesir, khususnya semakin banyaknya orang-orang terpelajar yang bergabung dengan gerakan ini. Tetapi, sepeninggal Al-Bannâ, gerakan ini tidak mempunyai pemimpin yang sehebat dan sekharismatik

\footnotetext{
${ }^{27}$ Al-Bannâ, Min Khultàb, 5.
}

${ }^{284}$ Majallat al-Ikhwan al-Muslimún" (13

Oktober 1945), hIm. 22-27.

${ }^{29}$ Rubin, Islamic Fundamontalism, 7.

30lbrahim, "An Islamic Alternative in Egypt," hlm. 90-91. 
Al-Bannâ. Karenanya, kemungkinan mengambil kekuasaan sepertinya masih jauh dari harapan. ${ }^{30}$

Jawaban negatif lain muncul dari Said Aly, yang menulis (1) berbeda dengan Iran, keberadaan organisasi politik di Mesir sudah ada lebih dari 50 tahun. Keadaan ini membuat gerakan-gerakan yang ada di Mesir lebih rumit memperbaiki keorganisasian maupun ekonominya; (2) berbeda dengan Iran, kebencian terhadap Barat di Mesir sangat kental. Akibatnya, kemungkinan masyarakat Mesir menerima produksi Barat seperti kapal terbang, alat transportasi dan lainnya, sangat tipis. Sementara Iran, walaupun benci terhadap barat tetapi masih menyadari pentingnya alat-alat itu. Padahal tanpa alat itu Ikhwan al-Muslimun hampir mustahil bisa mencapai cita-citanya; (3) berbeda dengan Iran, masyarakat Mesir adalah masyarakat Sunni yang tidak mengenal adanya konsep imamah. Padahal konsep imamah ini sangat memudahkan mereka untuk merealisasikan tujuan gerakan politik. ${ }^{31}$

Untuk menjawab pertanyaan kedua, Atho memberikan jawaban dari tiga sudut pandang, yakni dari tinjauan (i) struktur sosial, (ii) sejarah dan kebudayaan muslim Indonesia, dan (iii) ideologi politik Indonesia. Dari tiga tinjauan ini Atho akhirnya memberikan jawaban negatif terhadap kemungkinan terjadinya revolusi Islam di Indonesia. Dari tinjauan struktur sosial, bahwa muslim Iran yang mayoritas Syi'ah memiliki konsep imamah, sementara muslim Indonesia terdlri dari madhab Sunnl (Syâfi'îyah). Menurut konsep imamah, mengikuti perintah imam diyakini sebagai kewajiban agama yang tidak boleh dilanggar. Sementara dalam konsep Sunni keberadaan seorang alim (ulama) hanya sebagai pelindung. Maka ketetapan ula tidak diyakini wajib diikuti seperti yang keyakinan Syi'ah terhadap imamnya.
Bahkan adalah hal biasa kalau seorang muslim Sunni tidak senang dengan pandangannya seorang 'alim dia pergi ke 'alim lain untuk minta fatwa lain sesuai dengan keinginannya. Indonesia memang mempunyai lembaga ulama, yakni MUI, tetapi kedudukan MUl sangat berbeda dengan konsep imamah. Dari tinjauan sejarah dan budaya muslim Indonesia, bahwa Muslim Indonesia adalah muslim sinkretis dan sangat akomodatif. Sikap seperti ini umumnya sulit melakukan revolusi. Sementara dari tinjauan ideologi politik, Indonesia telah memproklamirkan Pancasila, sebagai ideologi negara. Terbukti pada tahun 1955 , Pemilu Indonesia pertama dan dicatat sebagai pemilu paling demokratis, akhirnya mengalami jalan buntu ketika sampai pada perbincangan tentang bentuk negara; negara Islam atau non Islam sebab suara yang memilih Indonesia dijadikan sebagai. negara Islam ternyata tidak mencapai $2 / 3$. Berbeda dengan lran yang memproklamirkan Islam sebagai dasar negara. Maka meskipun ada senipalan-sempalan yang tidak setuju Pancasila sebagai dasar negara, tetapi jumlahnya tidak mayoritas. ${ }^{32}$

\section{Kesimpulan}

Dari uraian tersebut dapat disimpulkan bahwa faktor yang menjadl latar belaking munculnya gerakan seperti Ikhwan alMuslimun adalah karena ketidakpuasan terhadap usaha modernisasi. Sebab, menurut mereka, kebijaksanaan-kebijaksanaan

\footnotetext{
359-360.

"Said Aly, "Modern Islamic Reform," him.

${ }^{32}$ Atho Mudzhar, "Iranian Revolution: Can It Happen to Indonesia?" Majalah al-Thalib, MSA-UCLA Newletter (Rajab 1409/Februari 1989), vol. 3, no. 5, him. 4-6.
} 
yang ditempuh dengan modernisasi tidak sejalan dengan ajaran agama Islam murni.

Oleh karena itu, mereka ingin diberi kesempatan untuk mericoba teorinya, sebagaimana para modernis diberikan kesempatan menerapkan teori mereka. Mereka bosań dengan slogan-slogan modernisme yang ternyata tidak memberikan hasil terbaik bagi masyarakat. Sementara tidak pernah diberi kesempatan untuk menguji dan mencoba keampuhan teori dan konsepnya.

Dapat berhasil atau tidak gerakangerakan Militan Islam memegang kekuasaan, ditentukan oleh banyak faktor, di an: taranya ideologi, kebudayaan, kemampuan gerakan ini meyakinan masyarakat bahwa gerakan mereka berusaha untuk mensejahterakan masyarakat luas, dan tingkat pendidikan masyarakat itu sendiri.

Wallahu a'lam bi al-sawab, semoga berguna, Amin.

\section{Daftar Pustaka}

Atho Mudzhar, "Iranian Revolution: Can it happen to Inddonesia?". Majalah alThalib, MSA-UCLA News letter (Rajab1409/Februari 1989), vol. 3, no. 5, hlm. 4-6.

Bannâ al-, Hasan, Mudhakkirat Hasan a/Bannâ. Kairo, tnp., 1949.

Esposito, John L., ed. Islam and Development: Religion and Sociopolitical Change. New York: Syracus University Press.
Hiro, Dipid, The Eise of Islamic Fundamentalism. New York: An Imprint of Rouledge, Chapman and Hall, Inc., 1989.

Holt, P.M., ed, Political and Social Change in Modern Egypt. tt.: tnp., 1968.

Ibrahim, Saad Eddin, "An Islamic Alternative in Egypt; The Muslim Brotherhood and Sadat," Arab Studies Quarterly 4: 1 \& 2 (1982), htm. 75 - 93.

Khoiruddin Nasution, "Hasan al-Banna dan Ikhwan al-Muslimun (Suatu Tinjauan Gerakan Pemikiran Sejak Berdiri sampai Masa Gamal Abdul Nasser)", al-Nawarid, edisi VI, Desember 1997. hIm. 104-113.

"Majalah al lkhwan àl-Muslimûn" (13 Oktober 1945), hlm. 22-27.

O'kane, Joseph $P_{4}$, "Islam in the New Egyption Constitutian," The Middle East Journal 26: 2 (Spring 1972): 137-148.

Rubin, Barry, Islamic in Search of Political Community: An Analysis of the Intellectual and Political Evolution of Egypt, 1804-1952. Cambridge university Press, 1961.

Satran, Nadav, Egypt in Search of Political Community: An Analysis of the Intellectual and Political Evolution of Egypt, 1804-1952. Cambrigde: Cambridge University Pres, 1961.

Said Aly, Abd ai-Monein dan Mantred W. Wenner, "Modern Islamic Reform Movements: The Muslim Brotherhood on Contemporary Egypt,"Midddle East Journal 36: 3 (Summer 1982): 336-361. 